\title{
Association between sports type and overuse injuries of extremities in adults: a systematic review
}

\author{
Charlène Chéron ${ }^{1,2,3^{*}} \mathbb{D}$, Christine Le Scanff ${ }^{1,2}$ and Charlotte Leboeuf-Yde $\mathrm{e}^{1,2,3}$
}

\begin{abstract}
Background: Sports injuries are often described as overuse or traumatic. Little is known about the frequency of overuse injuries and, in particular, if they vary between different types of sporting activities.

Purpose: To identify any differences between sports in relation to diagnoses of overuse injuries of the extremities (OIE) and anatomical areas most likely to be injured in adults and to compare these findings with those reported in youngsters, as identified in a previous review.

Methods: A search was made in May 2015 and again in April 2016 in PubMed, SportDiscus, Psyclnfo, and Web of Sciences. Search terms were « overuse injuries OR cumulative trauma disorders OR musculoskeletal injuries » AND « extremity OR limb » AND « physical activity OR sport OR risk factor OR exercises ». Inclusion criteria were: 1) prospective, or cross-sectional study design; 2) at least 1/3 of the population should be $\geq 19$ years; 3 ) articles must clearly state if reported cases were classified as traumatic or overuse injuries in relation to a particular sports type, 4) sample size $>50$, and 5) articles must not deal with specific occupational subpopulations nor with clinical populations. A blinded systematic review was conducted and results reported per anatomical site of injury and diagnosis for the different sports.

Results: In all, 10 of 1435 identified articles were included, studying soccer, beach-volleyball and triathlon. In general, the incidence estimates were low, never above 2.0/1000 h of practice, similar to results seen in children/adolescents. The incidence estimates and the diagnoses of OIE were given only in 4 articles on soccer, making comparisons between sports impossible. As in children/adolescents, the lower limb is more often affected than the upper but contrary to young people the injured site in adults is more often the knee and above, and there were also differences in the diagnoses for the two age groups.

Conclusion: The literature does not permit to identify clearly the difference in the incidence of OIE for different sports showing that more but well-designed surveillance studies are needed.
\end{abstract}

Keywords: Cumulative trauma disorders, Overuse injuries, Sports type, Extremities, Epidemiology, Adults

\section{Background}

Physical activity promotes the general well-being and has many direct health benefits [1-3]. Nevertheless, physical activity can also cause injuries that in turn may be responsible for reduced physical activities and even an inability to work. Moreover, these injuries may require medical care including surgery and perhaps long periods

\footnotetext{
* Correspondence: cheron.charlene@ifecetud.net

${ }^{1}$ CIAMS, Université Paris-Sud, Université Paris-Saclay, F-91405 Orsay, Cedex, France

${ }^{2}$ CIAMS, Université d'Orléans, F-45067 Orléans, France

Full list of author information is available at the end of the article
}

of rehabilitation. This may result in costs both on an individual and societal level.

Classically, injuries can be defined as traumatic or overuse depending on their etiology. An important prospective study following 1270 schoolchildren weekly by text-messages (and clinical examination if needed) regarding musculoskeletal injuries and physical activity brought a lot of information on musculoskeletal injuries. In order to study the epidemiology of musculoskeletal injury this method appeared to be more relevant than what is commonly seen in the literature in which data collection is usually performed in sports' clubs, during a 
sporting event or using medical files. In this study it was found that overuse was a more common cause of reported injuries to the extremities than obvious trauma [4]. In addition, it was noted that the lower extremities were more commonly injured than the upper extremities.

A recent literature review on the link between overuse injuries of extremities (OIE) and specific types of sport in children and adolescents concluded that it was not possible to determine and compare the incidence of OIE between sports due to methodological heterogeneity of studies [5]. Although, in general, the most commonly injured sites are the knee and the heel [4], the risk of reported injury differed somewhat between sports in relation to anatomical site. Interestingly, sports that put a lot of strain on the upper extremity, such as handball and volleyball resulted in overuse injuries of the lower extremity at least as often as of the upper extremity. It was also noted that the three most common diagnoses of OIE are tendinitis/bursitis, strain and osteochondral disorders across all sports [4] and these do not change between sports [5]. Unfortunately, articles often did not report clearly exact site and diagnosis of injuries.

The skeleton of children and adults do not have the same consistency and maturity, so this information relating to children may not be applicable to adults. To our knowledge, no clear information is available on sportsrelated OIE for the adult population.

For this reason, we conducted a systematic review to gain a better understanding of sports-specific OIE in adults with three objectives:

1. To determine the incidence of OIE for various sports

2. To identify any differences between sports in relation to the anatomical areas most likely to be injured

3. To identify any differences between sports in relation to diagnosis

To be able to compare the findings on adults to those in children, we used a similar method to our previous review on children and adolescents [5].

\section{Methods}

\section{Systematic literature search}

A first search was performed in May 2015 and a final search in April 2016 in PubMed, SportDiscus, PsycInfo, and Web of Sciences using the search terms " overuse injuries OR cumulative trauma disorders OR musculoskeletal injuries » AND « extremity OR limb » AND « physical activity OR sport OR risk factor OR exercises » in different combinations (MeSH terms and free text). An additional citation search of reference lists of the retrieved articles was performed. No restrictions were placed on date of publication and no attempts were made to search the grey literature.

\section{Inclusion criteria}

We used the Preferred Reporting Items for Systematics reviews and Meta-Analysis (PRISMA) guidelines in this review [6]. The first author applied the inclusion criteria to the title and abstract of the articles identified as possible relevant research articles from the literature search. Full-text screening was then done by two authors independently of each other to determine which articles should be included in the review. Inclusion criteria were: 1) a study design that was prospective or crosssectional; 2) at least $2 / 3$ of the study population should consist of $\geq 19$ years olds or results should be reported specifically for different age groups. To determine this we looked for information on the range age, the mean age with the standard deviation, and the proportion of adults, when data were reported for age groups. In study samples consisting of "professionals" but no further information of age, we assumed that these would consist mainly of adults; 3 ) the article must state clearly if reported cases were classified as traumatic or overuse injuries in relation to a particular sports type; 4) a sample size greater than 50; and 5) the article must not deal with specific occupational subpopulations (such as military) nor with clinical populations. Only articles in English, French or a Scandinavian language were considered, as the authors could read these languages.

\section{Data extraction}

The checklists were extracted from a previous review on OIE and sports' type on children and adolescents [5]. We used two descriptive checklists, one quality checklist and three tables of results [5].

Table 1 included information on the first author, year of publication, type of sport and level (recreational or elite). Moreover, we reported the number of subjects invited, the number and age of participants, the duration and the method of data-collection, and a description of the person who collected the information and/or diagnosed the injury.

Table 2 specified the criteria used in the article to define "injury" and "overuse injury" inspired respectively by Bahr [7] and Fuller [8]. The criteria for "injury" were: sportrelated, complaint, time-loss, and medical attention. Regarding the definition of "overuse" we used: 1) repeated micro trauma, 2) no single, identifiable cause; 3) activity exceeds tissue tolerance and 4) gradual onset. Because some articles used other criteria, we added the column "other". For a discussion of the rationale behind these definitions, please see our previous publication, where this is explained in detail [5].

The quality checklist can be seen in Table 3 . It was reported in this table if 1 ) the participation rate was stated (or could be calculated), 2) the injury was diagnosed by a health professional, 3) the diagnosis and 


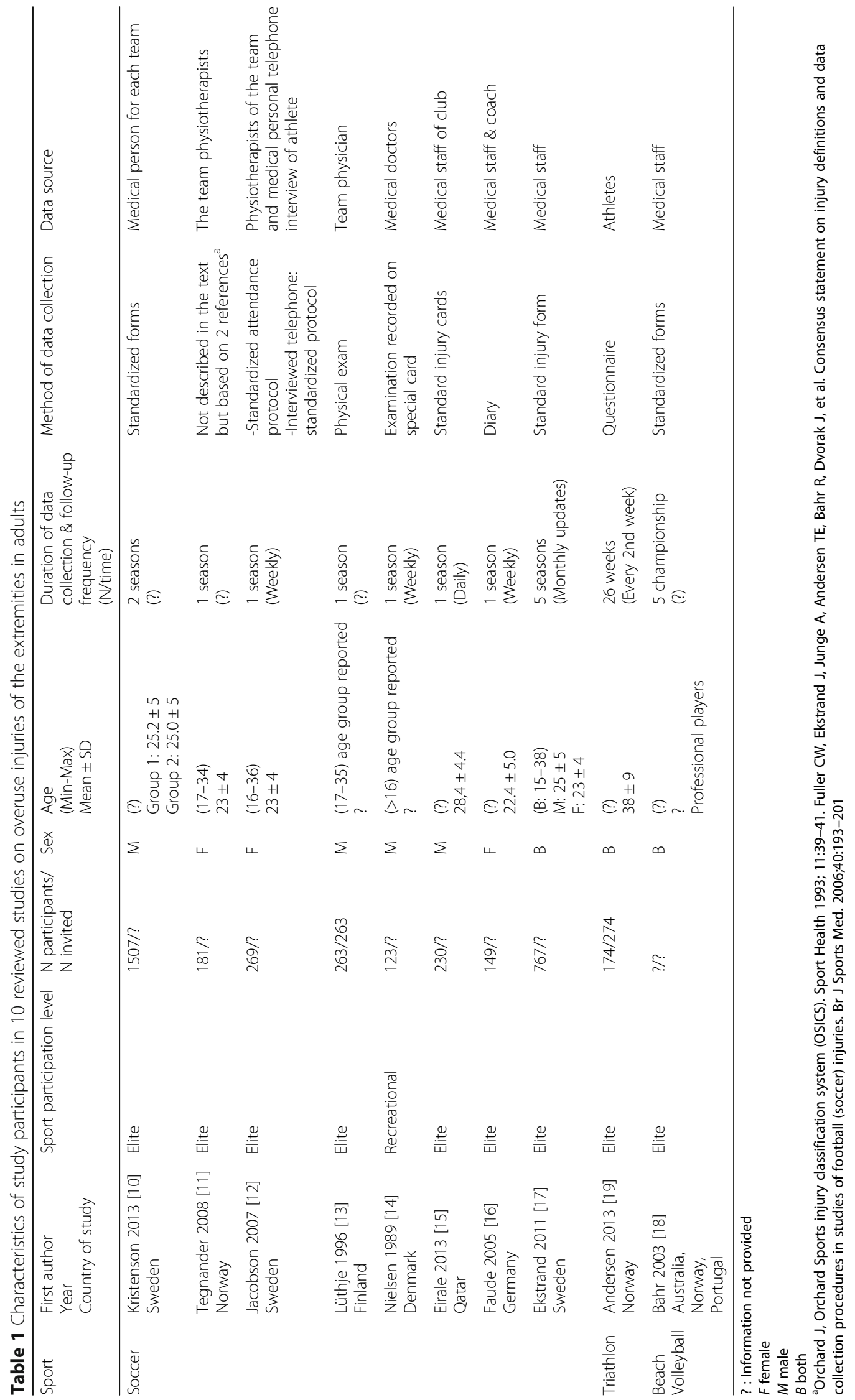




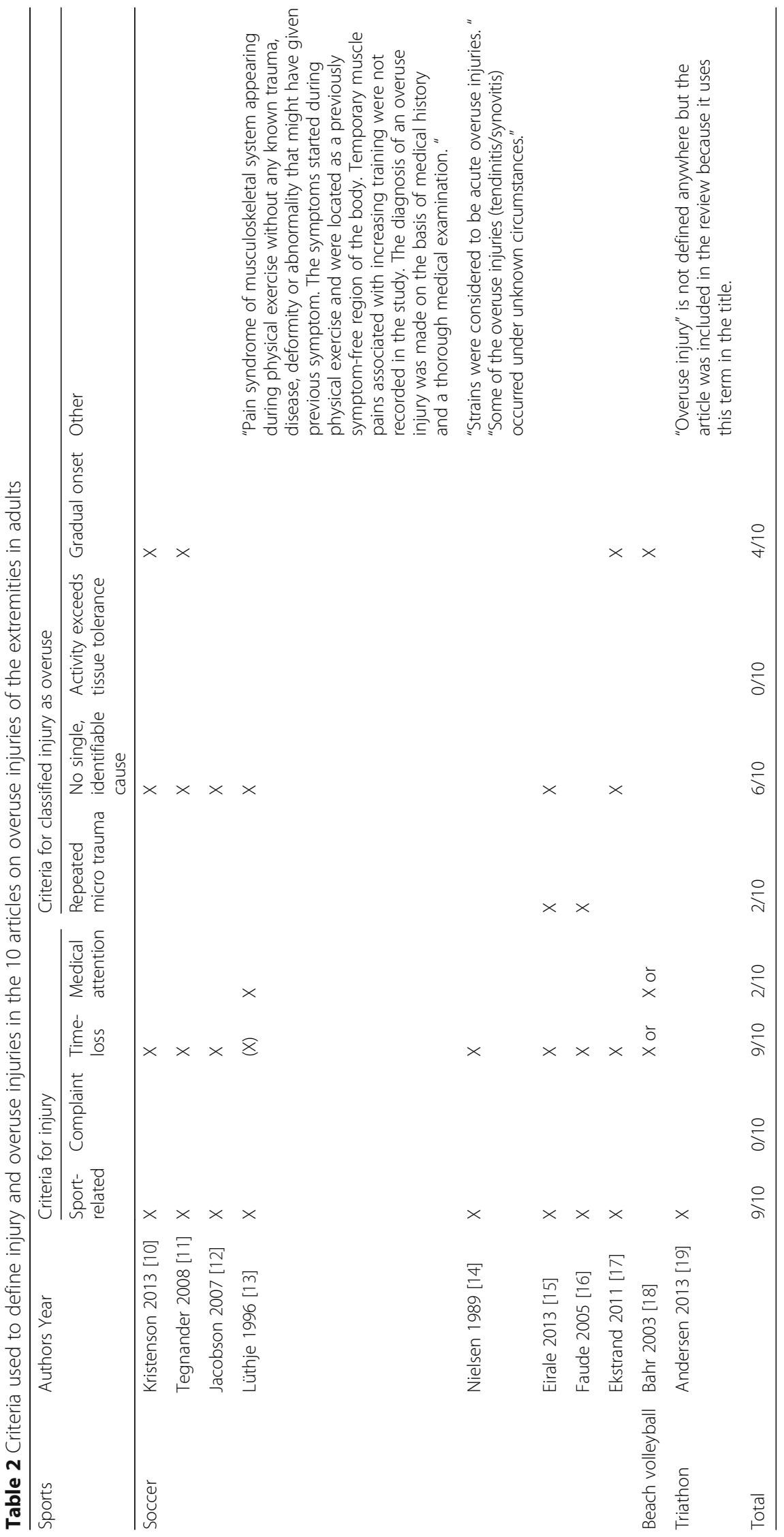


Table 3 Quality checklist of methodological aspects of 10 studies on overuse injuries of the extremities (OIE) in adults

\begin{tabular}{|c|c|c|c|c|c|c|c|c|c|}
\hline \multirow[t]{2}{*}{ Sport } & \multirow[t]{2}{*}{$\begin{array}{c}\text { Author } \\
\text { Year }\end{array}$} & \multirow{2}{*}{$\begin{array}{c}\text { Was } \\
\text { participation } \\
\text { rate reported } \\
\text { or possible to } \\
\text { calculate? } \\
(\mathrm{Y}(\%) / \mathrm{N})\end{array}$} & \multirow{2}{*}{$\begin{array}{l}\text { Was overuse } \\
\text { injury } \\
\text { information } \\
\text { provided by } \\
\text { health } \\
\text { professional? }\end{array}$} & \multirow{2}{*}{$\begin{array}{l}\text { Were all relevant } \\
\text { anatomical areas } \\
\text { studied clearly } \\
\text { reported? }\end{array}$} & \multirow[t]{2}{*}{$\begin{array}{c}\text { Were all relevant } \\
\text { diagnoses clearly } \\
\text { reported? }\end{array}$} & \multirow{2}{*}{$\begin{array}{c}\text { Was } \\
\text { incidence of } \\
\text { OIE } \\
\text { reported? }\end{array}$} & \multicolumn{2}{|c|}{$\begin{array}{l}\text { Was denominator reported both } \\
\text { as number of individuals and } \\
\text { number of hours/sessions? }\end{array}$} & \multirow[t]{2}{*}{ Total score } \\
\hline & & & & & & & Individuals & Hours & \\
\hline \multirow[t]{8}{*}{ Soccer } & $\begin{array}{c}\text { Kristenson } \\
2013\end{array}$ & $\mathrm{~N}$ & $\mathrm{Y}$ & $\mathrm{Y}$ & $\mathrm{N}$ & $\mathrm{N}$ & $\mathrm{Y}$ & $\mathrm{Y}$ & $4 / 7$ \\
\hline & $\begin{array}{l}\text { Tegnander } \\
2008\end{array}$ & $\mathrm{~N}$ & $\mathrm{Y}$ & $Y$ & $\mathrm{~N}$ & $\mathrm{Y}$ & $\mathrm{Y}$ & $\mathrm{Y}$ & $5 / 7$ \\
\hline & $\begin{array}{c}\text { Jacobson } \\
2007\end{array}$ & $\mathrm{~N}$ & $\mathrm{Y}$ & $\mathrm{Y}$ & $\mathrm{N}$ & $\mathrm{Y}$ & $\mathrm{Y}$ & $\mathrm{Y}$ & $5 / 7$ \\
\hline & $\begin{array}{l}\text { Lüthje } \\
1996\end{array}$ & $\mathrm{Y}(100 \%)$ & $\mathrm{Y}$ & $\mathrm{N}$ & $\mathrm{N}$ & $\mathrm{N}$ & $\mathrm{Y}$ & $\mathrm{N}$ & $3 / 7$ \\
\hline & $\begin{array}{l}\text { Nielsen } \\
1989\end{array}$ & $\mathrm{~N}$ & $\mathrm{Y}$ & $\mathrm{N}$ & $\mathrm{Y}$ & $\mathrm{N}$ & $\mathrm{Y}$ & $\mathrm{Y}$ & $4 / 7$ \\
\hline & $\begin{array}{l}\text { Eirale } \\
2013\end{array}$ & $\mathrm{~N}$ & $\mathrm{Y}$ & $\mathrm{Y}$ & $\mathrm{Y}$ & $\mathrm{Y}$ & $\mathrm{Y}$ & $\mathrm{Y}$ & $6 / 7$ \\
\hline & $\begin{array}{l}\text { Faude } \\
2005\end{array}$ & $\mathrm{~N}$ & $\mathrm{Y}$ & $\mathrm{N}$ & $\mathrm{N}$ & $\mathrm{N}$ & $\mathrm{Y}$ & $\mathrm{Y}$ & $3 / 7$ \\
\hline & $\begin{array}{l}\text { Ekstrand } \\
2011\end{array}$ & $\mathrm{~N}$ & $\mathrm{Y}$ & $\mathrm{Y}$ & $\mathrm{N}$ & $\mathrm{Y}$ & $\mathrm{Y}$ & $\mathrm{N}$ & $4 / 7$ \\
\hline Triathlon & $\begin{array}{l}\text { Andersen } \\
2013\end{array}$ & $\mathrm{Y}(63.5 \%)$ & $\mathrm{N}$ & $\mathrm{Y}$ & $\mathrm{N}$ & $\mathrm{N}$ & $\mathrm{Y}$ & $\mathrm{Y}$ & $4 / 7$ \\
\hline $\begin{array}{c}\text { Beach } \\
\text { volleyball }\end{array}$ & $\begin{array}{l}\text { Bahr } \\
2003\end{array}$ & $\mathrm{~N}$ & $\mathrm{Y}$ & $\mathrm{Y}$ & $\mathrm{N}$ & $\mathrm{N}$ & $\mathrm{N}$ & $\mathrm{Y}$ & $3 / 7$ \\
\hline \multicolumn{2}{|c|}{ Total } & $2 / 10$ & $9 / 10$ & $7 / 10$ & $2 / 10$ & $4 / 10$ & $9 / 10$ & $8 / 10$ & \\
\hline
\end{tabular}

$N$ no

$Y$ yes; when positive answers have been highlighted

anatomical site were clearly and completely reported, 4) the incidence of OIE was reported, and 5) if the number of injuries could be reported in relation to number of hours of exposure and individuals.

Three evidence tables reported the findings. Table 4 reported the estimates of rates of OIE. The incidence was included if it was clearly reported in the article.
Moreover, we calculated the proportion of OIE based on the total number of hours of exposure and reported this as number of injuries per $1000 \mathrm{~h}$ of exposure.

In Table 5 the numbers of OIE were listed by anatomical area. We highlighted those two that were most commonly reported. Table 6 showed the same type of information but based on the diagnosis.

Table 4 Incidence and proportion of overuse injuries of the extremities (OIE) based on numbers of hours of exposure in 10 studies on adults

\begin{tabular}{|c|c|c|c|c|c|}
\hline Sport & Author Year & Number of OIE & Incidence estimate given in the article & $\begin{array}{l}\text { Number of hours } \\
\text { of exposure }\end{array}$ & $\begin{array}{l}\text { Proportions of OIE } \\
\text { based on number } \\
\text { of hours of exposure } \\
\left({ }^{*} 1000\right)\end{array}$ \\
\hline \multirow[t]{9}{*}{ Soccer } & Kristenson 2013 [10] & 406 & - & 367490 & 1.10 \\
\hline & Tegnander 2008 [11] & 21 & $\begin{array}{l}0.8 \text { per } 1000 \text { game hours } \\
0.7 \text { per } 1000 \text { training hours }\end{array}$ & 30619 & 0.68 \\
\hline & Jacobson 2007 [12] & 62 & $\begin{array}{l}\text { Between } 0.0 \text { to } 0.6 \\
\text { depending on area }\end{array}$ & 47075 & 1.32 \\
\hline & Lüthje 1996 [13] & 16 & - & - & - \\
\hline & Nielsen 1989 [14] & 30 & - & 15908 & 1.89 \\
\hline & & 79 & - & 23400 & 3.38 \\
\hline & Eirale 2013 [15] & 115 & $\begin{array}{l}\text { From } 0.03 \text { to } 2.0 \text { (varying } \\
\text { depending on diagnosis } \\
\text { \& localisation) }\end{array}$ & 39100 & 2.94 \\
\hline & Faude 2005 [16] & 7 & - & 39162 & 0.18 \\
\hline & Ekstrand 2011 [17] & $?$ & $\begin{array}{l}\text { From } 0 \text { to } 0.5 \text { (depending } \\
\text { on diagnosed area) }\end{array}$ & $\begin{array}{l}\text { M: } 198071 \\
\text { F: } 48404\end{array}$ & - \\
\hline Triathlon & Andersen 2013 [19] & 403 & - & 48024 & 8.39 \\
\hline Beach volleyball & Bahr 2003 [18] & $\begin{array}{l}21 \\
\text { Estimates from diagram }\end{array}$ & - & 1576 & 13.32 \\
\hline
\end{tabular}


Table 5 Site of overuse injury of the extremities by sports in 10 studies on adults

\begin{tabular}{|c|c|c|c|c|c|c|c|c|c|c|}
\hline & & & & & occer & & & & Triathlon & Beach volley- \\
\hline Injury $\begin{array}{c}\text { Author } \\
\text { Localisation }\end{array}$ & $\begin{array}{c}\text { Kristenson } \\
2013\end{array}$ & $\begin{array}{c}\text { Tegnander } \\
2008\end{array}$ & $\begin{array}{c}\text { Jacobson } \\
2007\end{array}$ & $\begin{array}{l}\text { Lüthje } \\
1996\end{array}$ & $\begin{array}{c}\text { Nielsen } \\
1989\end{array}$ & $\begin{array}{l}\text { Eirale } \\
2013\end{array}$ & $\begin{array}{l}\text { Faude } \\
2005\end{array}$ & $\begin{array}{c}\text { Ekstrand } \\
\text { 2011* }\end{array}$ & $\begin{array}{c}\text { Andersen } \\
2013\end{array}$ & $\begin{array}{l}\text { Bahr } \\
2003\end{array}$ \\
\hline $\begin{array}{l}\text { TOTAL } \\
\text { REPORTED } \\
\text { OIE }\end{array}$ & 406 & 21 & 62 & 16 & 30 & 115 & 7 & & 403 & 25 \\
\hline $\begin{array}{l}\text { UPPER } \\
\text { EXTREMITY } \\
\text { TOTAL } \\
\end{array}$ & $?$ & 0 & 1 & 0 & $?$ & 1 & $?$ & & 89 & 7 \\
\hline Shoulder & $?$ & 0 & $?$ & 0 & $?$ & 1 & $?$ & & 88 & 4 \\
\hline Arm & $?$ & 0 & $?$ & 0 & $?$ & 0 & $?$ & & 0 & 1 \\
\hline Elbow & $?$ & 0 & $?$ & 0 & $?$ & 0 & $?$ & & 1 & 0 \\
\hline Forearm & $?$ & 0 & $?$ & 0 & $?$ & 0 & $?$ & & 0 & 0 \\
\hline Wrist & $?$ & 0 & $?$ & 0 & $?$ & 0 & $?$ & & 0 & 0 \\
\hline $\begin{array}{l}\text { Hand/ } \\
\text { Fingers }\end{array}$ & $?$ & 0 & $?$ & 0 & $?$ & 0 & $?$ & & 0 & 2 \\
\hline $\begin{array}{l}\text { LOWER } \\
\text { EXTREMITY } \\
\text { TOTAL }\end{array}$ & 406 & 21 & 61 & 16 & 30 & 114 & 7 & & 314 & 14 \\
\hline $\begin{array}{l}\text { Pelvis/Hip/ } \\
\text { Groin }\end{array}$ & 177 & 3 & 3 & $?$ & $?$ & 18 & $?$ & (4) & 5 & 1 \\
\hline Thigh & 96 & 3 & 1 & $?$ & 22 & 62 & $?$ & (1) & 88 & 4 \\
\hline Knee & 74 & 8 & 29 & $?$ & 4 & 15 & 5 & (3) & 106 & 8 \\
\hline $\begin{array}{l}\text { Tibia/Calf/ } \\
\text { Achilles }\end{array}$ & 59 & 5 & 13 & $?$ & $?$ & 17 & 2 & (2) & 106 & 1 \\
\hline Ankle & $?$ & 1 & 6 & $?$ & 2 & 1 & $?$ & (5) & 2 & 0 \\
\hline Foot/Toes/Heel & $?$ & 1 & 9 & $?$ & 2 & 1 & $?$ & & 7 & 0 \\
\hline
\end{tabular}

The two most common injury sites in each article are highlighted: Like this for the most common and like this for the second most common "?"= Information not provided

OIE: Overuse injuries of extremities

Articles in which all OIE are described and in which all the sites of OIE are clearly described are framed, i.e. Author/Year

*: the number of injuries was not reported in this article but we have the incidence so we could rank the localisation. 1 means the most often reported, 2 , the 2 nd most often, and so on

Table 6 Injury diagnosis according to sports type for 4 studies on adults that included specific diagnosis

\begin{tabular}{|l|c|c||c|c|}
\hline \multicolumn{4}{|c|}{ soccer } \\
\hline $\begin{array}{l}\text { Author } \\
\text { Year }\end{array}$ & $\begin{array}{c}\text { Kristenson } \\
2013\end{array}$ & $\begin{array}{c}\text { Nielsen } \\
1989\end{array}$ & $\begin{array}{c}\text { Eirale } \\
2013\end{array}$ & $\begin{array}{c}\text { Ekstrand } \\
2011^{*}\end{array}$ \\
\hline $\begin{array}{l}\text { TOTAL } \\
\text { REPORTED } \\
\text { OIE }\end{array}$ & $\mathbf{4 0 6}$ & $\mathbf{3 0}$ & $\mathbf{1 1 5}$ & \\
\hline $\begin{array}{l}\text { Tendinitis/ } \\
\text { bursitis }\end{array}$ & 75 & 10 & 26 & $(1)$ \\
\hline Strain & $?$ & 20 & $\begin{array}{c}72 \\
\text { muscle rupture } \\
\text { strain+cramps }\end{array}$ & $(3)$ \\
\hline Stress fracture & $?$ & 0 & 2 & $?$ \\
\hline Periostitis & $?$ & 0 & 3 & $?$ \\
\hline Synovitis & $?$ & 0 & & $?$ \\
\hline Fascitiis & $?$ & 0 & 7 & $?$ \\
\hline $\begin{array}{l}\text { Meniscus/ } \\
\text { cartilage }\end{array}$ & $?$ & 0 & $?$ & $?$ \\
\hline Other & $?$ & 0 & & $?$ \\
\hline
\end{tabular}

OIE: Overuse injuries of extremity

The two most common diagnoses in each article are highlighted: Like this for the most common and like this for the second most common

Six articles have been excluded in this table because they did not mention any diagnosis:

Articles in which all OIE are described and in which all the diagnosis of OIE are clearly described are framed, i.e. Author/Year

*: The number of injuries was not reported in this article but we have the incidence so we could rank the diagnoses. "1" means the most often reported, "2" the 2nd most often, and so on 
The AMSTAR checklist [9] was used as a guide for this review. However, tests for homogeneity and publication bias were not carried out because no such statistical information could be extracted to be used in this review. Furthermore, articles were not screened for conflict of interest statements, as this aspect was irrelevant for the current topic (no obvious financial gains).

\section{Review process and interpretation of data}

Two of the authors extracted the information separately and blind to each other's findings. Their findings were compared to detect extraction errors. The third author was available for arbitration in case of disagreements between the two reviewers. The quality data were used for descriptive purpose only and to provide a basis for research recommendations.

The review was registered in the PROSPERO database: CRD42015032477.

\section{Results}

\section{Number of articles}

Initially, on the basis of the database and citation searches, 1435 articles were identified, leaving 1080 articles after duplicates were removed. Of these, only 10 were retained after scrutiny of their title, abstract and full-text. The criteria of non-inclusion of the articles are presented in Fig. 1. Most of the excluded studies did not deal with specific sports or OIE. Although it often was difficult to extract some of the data, it was never necessary to use the arbitration process.

\section{Study design, participants and method}

Three sports were covered in the 10 articles included in this review: soccer [10-17], beach volleyball [18], and triathlon [19]. They were published from 1989 to 2013 and nine were conducted in Europe. The design was prospective for all studies except for one [18], which combined a prospective and retrospective study, but only results from the prospective study were used in this review. In all studies, the study samples were obtained from sports clubs or at competitions. The level of sport participation of the study participants varied from recreational to elite level, but for the majority of articles it was at an elite level.

The number of participants ranged from 123 to 1507 (Table 1). Four studies included only men, three studies only women, and three studies both sexes (Table 1). The age of participants was not clearly described in all articles, but when it was, it varied from 15 to 39 (Table 1), with the mean age of 23 to 38 years.

The duration of data collection, when described, ranged from 26 weeks to 2 seasons and for one article it took place during five championships. The frequency of follow-ups within this duration, when reported, was often weekly (Table 1).

\section{Definition of overuse sport injuries}

The definition of 'sports injury' differed between articles (Table 2). Most commonly, a case was defined by timeloss and was nearly always depending on a link to the specific sport activity studied. The specific definition of overuse injury was most commonly based on the concept

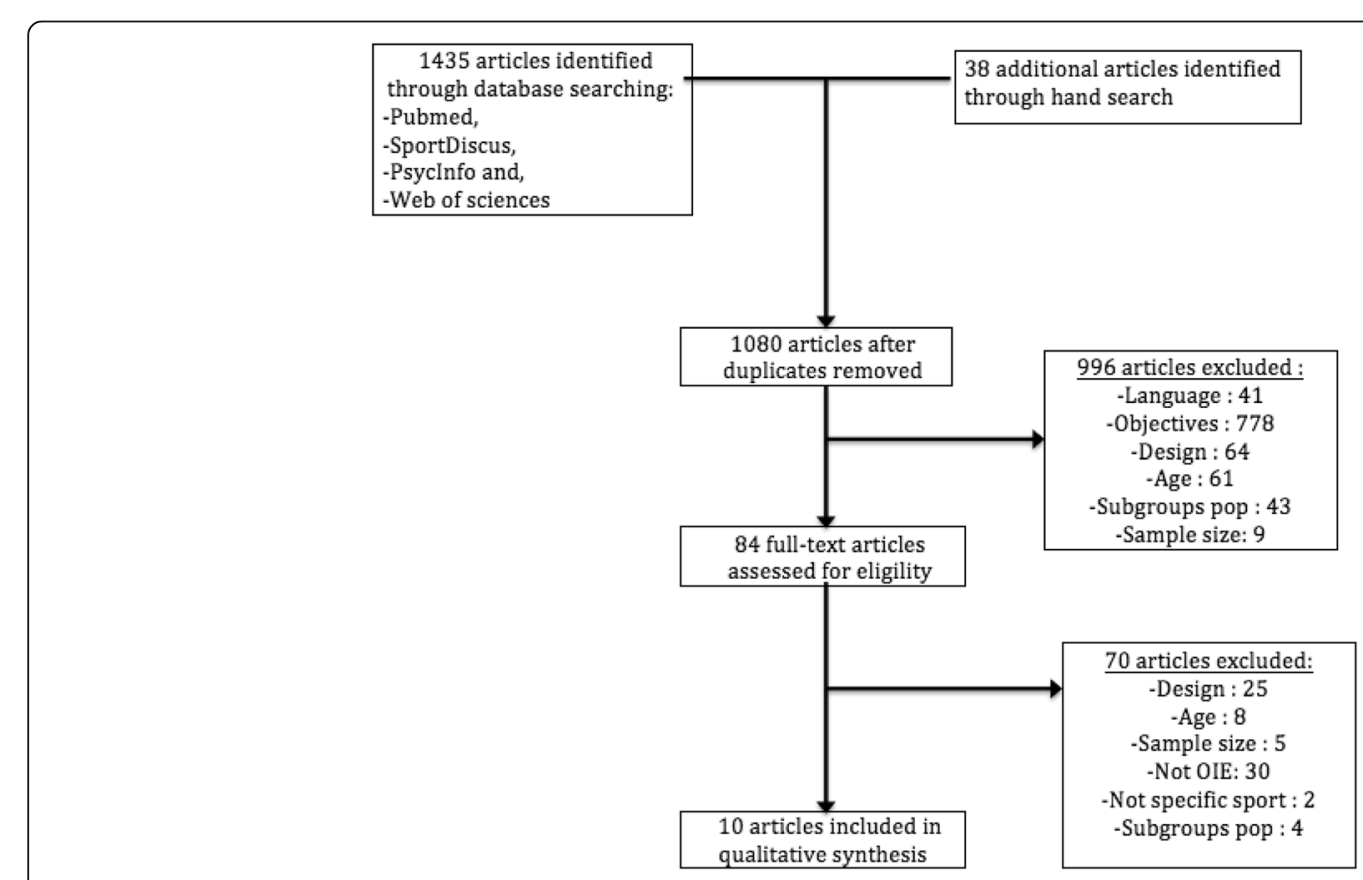

Fig. 1 PRISMA flowchart showing selection of articles 
of the absence of a single, identifiable (traumatic) cause $(N=6)$, followed by gradual onset $(N=3)$, repeated micro-trauma $(N=2)$, and combinations thereof. Nobody stated explicitly that the activity had to exceed tissue tolerance, although this probably would have been taken into consideration during medical examination.

\section{Quality of the studies}

Although method sections in this type of studies often are very similar, specific information was sometimes difficult to obtain for our purposes. As can be seen in Table 3, response rates were often unreported, as well as incidence estimates. Therefore, it became necessary to calculate the proportion of cases based on exposure, which explains the last column in the quality checklist. In relation to outcomes, overuse injuries per anatomical area and diagnosis were often not systematically reported. On the positive side, health professionals were usually responsible for the data collection.

\section{Incidence estimates of overuse injuries}

The incidence estimates of OIE are shown in Table 4. These were reported in only four articles dealing with soccer but they all reported it differently.

Tegnander et al. [11] calculated the incidence distinguishing training from game exposure. Moreover, they reported the incidence for OIE in general with incidence estimates of OIE being 0.8 per $1000 \mathrm{~h}$ of game and 0.7 per $1000 \mathrm{~h}$ of training.

The other three articles reported the incidence based on $1000 \mathrm{~h}$ of sport participation. Jacobson et al. [12] provided the incidence for OIE based on the area injured, which varied from 0 for the hip, groin and thigh to 0.6 for the knee. Eirale et al. [15] provided the incidence for various diagnoses and localisations. Regarding the diagnoses, the incidence varied from 0.1 for fracture and synovitis/periostitis to 2.0 for muscle rupture/cramps. Regarding the localisation, the incidence estimates varied from 0.03 for shoulder, ankle and foot/ toe to 1.7 for the thigh. Ekstrand et al. [16] reported the incidence for the most common OIE subtypes while combining the diagnosis and the localisation. The incidence varied from 0.03 for the ankle joint synovitis and calf muscle cramp/spasm to 0.5 for hamstring overuse/ hypertension.

\section{Proportion estimates of overuse injuries}

Table 4 shows also the proportion of OIE based on exposure. It could be calculated in 8 articles and varied from 0.18 to 13.32 per $1000 \mathrm{~h}$ of exposure. The two studies that did not study soccer reported higher proportion of OIE than the others. Methodological differences could probably explain these results.

\section{Injury site and diagnosis in general}

The lower limb was most often affected (Table 5) and especially the knee, tibia, thigh and pelvis/hip/groin.

Only few articles described the diagnosis of overuse injury. For that reason, only 4 articles could be included in Table 6 . The most frequently provided diagnoses were tendinitis/bursitis, and strain.

\section{Differences in overuse injuries according to sports type}

For all sports covered, the lower limb was more often affected than the upper limb. Again, it was impossible to compare the incidence rates between sports, because it was only reported in the articles on soccer. When considering the proportion of OIE per $1000 \mathrm{~h}$ of exposure, different results are found. For soccer, this proportion is $<3.5$ (and often around 1), 8 for triathlon, and 13 for beach volleyball. However, methodological considerations could well explain these differences.

In soccer, the pelvis/hip/groin appeared to be more commonly affected than in the two other sports.

We could not compare the diagnosis of OIE between sports because only articles on soccer reported the diagnosis.

\section{Discussion}

\section{Summary of findings}

This appears to be the first systematic review on OIE in adults comparing the occurrence in various sports. We attempted to identify any differences between sports in relation to diagnoses and anatomical areas most likely to be injured. We were able to retrieve 10 studies on three different sports: soccer $(N=8)$, triathlon $(N=1)$ and beach volleyball $(N=1)$. Methodological differences between studies and a limited number of studies and sports studied made it difficult to provide clear answers. However, in relation to the proportion of OIE it varied between 0.2 to 13.3 per $1000 \mathrm{~h}$ of exposure, with soccer not having the highest estimates. This proportion is generally more important in adults than in youngsters, where results around 0.5 were found [5].

Injury site was, as for the youngsters [5], mainly the lower limb. However, in adults this was reported rather for the knee, tibia, thigh and pelvis/hip/groin whereas in youngsters it was the knee and the lower leg.

As for the diagnoses, they were most frequently (when at all provided) reported to be tendinitis/bursitis, and strain, whereas in children and adolescents the most commonly reported diagnoses were tendinitis/bursitis and periostitis [5].

\section{Methodological aspects of the articles reviewed}

A large body of literature on sports injuries of adults, as well as of children, is written by a group of researchers that uses the same methodological approach when 
surveying injuries in different sports. Typically, they study injuries in single sport clubs or during specific sports events with the ultimate goal to compare risk estimates for various sport activities. To record a sufficiently large number of injuries of specific sports in the general population is of course difficult, hence this approach. However, when choosing such a tactic, it would be relevant to collect similar data from several clubs/events, in order to even out any bias associated with single convenience samples of such type.

After having reviewed this literature on both children/ adolescents and adults, it is clear that even when multiple studies are found for similar sports, data are often collected at different intervals, in different ways, using different definitions for injury, and for different specific types of injuries. Authors do not clearly report diagnosis and anatomical areas of injury, and if they do, they often leave out the one or the other. This, also, makes it difficult to make comparisons and to establish risk estimates. A simple example is the difference in estimates expected when the presence of an "injury" is reported as "complaint", as "sought care", or "time loss". Further, in the case of "overuse", absence of a traumatic etiology seems often automatically to result in a diagnosis of an "overuse" injury, merely because the person with the complaint was involved in a sporting activity. It is not logical that people involved in studies on sport injuries only have these two possible diagnoses, traumatic or overuse injury. Surely patients from the general population are diagnosed from a larger spectrum of possibilities. Clear criteria for this diagnostic label have been proposed [5] and discussed in the literature [20], but seem to be largely ignored, at least when reports are written up.

As for the definitions of "incidence" and "prevalence", true incidence and prevalence estimates are usually not distinguished in studies within this area. The incidence is defined as number of injuries based on $1000 \mathrm{~h}$ of session (training, competition or both), in general without regards concerning the previous injury. In fact, this should not really be called incidence but prevalence. This issue has been previously discussed by Bahr [7]. Further, the numbers of potential and included study subjects are often not reported. Clearly, an injury rate (per $1000 \mathrm{~h}$ ) would be more credible when obtained from many study subjects than from a few. It would therefore be useful for the reader to have access to both these denominators.

Admittedly, the objectives of our review were not the same as the objectives of the studies under review, which makes difficult the extraction of information in our review. Nevertheless, as we have already discussed in our previous review on children/adolescents [5] in our opinion, this research area would benefit from a well-reasoned consensus approach to the various definitions.

\section{Methodological aspects of our review}

Our review followed the current guidelines, using a transparent approach, searched several databases, and data were extracted blindly by two reviewers. However, it is possible that some articles could have been missed, as only texts written in English, French and Scandinavian languages were acceptable for inclusion. Checklists for data extraction have been previously tested and used in a previous review and were therefore known to be user-friendly and relevant.

Sometimes we had to make assumptions regarding the nature of injuries, when exact information regarding the site of injury was missing. Thus two diagnoses, tendinopathy and periostitis, were systematically considered as extremity injuries, whereas some diagnoses such as strain was not, because it could affect the spine.

\section{Discussion of findings regarding the incidence of OIE}

We did not find any information in the literature on OIE in the general population of adults. However, the incidence of OIE in general population of schoolchildren has been reported to be 2.3(1.6-3.0 95\% CI) for the upper extremity and 3.7(3.5-4.0) for the lower extremity [4].

\section{Discussion of findings regarding the anatomical site of OIE}

As observed in the previous review on children and adolescents [5], the lower extremity is more often affected than the upper extremity in the sports studied. Only three sports could be considered in this review, so it is difficult to compare the localisation of OIE between sports. However, we noted that in soccer, in youngsters and in adults, the pelvis/hip/groin are more often affected than in the other sports. We assumed that this is due to the shearing force often imposed on the pelvis in soccer.

\section{Discussion of findings regarding the diagnosis of OIE} Only four articles provided good information on the diagnosis of OIE and they all studied soccer, making it impossible to compare this finding with other sports. In childhood, 8 articles reported the diagnosis making a comparison relevant. However, for all sports covered, it was always the two same diagnoses that were reported.

Tendinis/bursitis is the most common diagnosis both in childhood and adulthood, followed in adults by synovitis, and in youngsters by periostitis. Probably because of the difference in bone skeletal maturity, osteochondral disorders, present in youngsters, did not appear in adults.

\section{Conclusion}

This research area suffered from lack of information because of few relevant studies and methodological 
problems, which makes difficult the extraction and comparison of the incidence of OIE in relation to both their diagnosis and localisation. However, we could conclude that the incidence of OIE is low in adulthood, as it was previously found to be in childhood, across most studies reviewed. The localisation of OIE seems to be predominantly in the lower limb, with some differences relating to exact anatomical area between sports. Obviously, the search for risk sports and specific types of injuries needs to be undertaken in a more systematic and homogeneous manner, to make the information useful for the purposes of prevention.

\section{Abbreviation \\ OIE: Overuse injuries of extremities}

\section{Acknowledgements}

Not applicable.

\section{Funding}

Apart from the authors being funded from their institutions, there were no external grants for this project.

Availability of data and materials

Not applicable.

\section{Authors' contributions}

The three authors formulated the research question and helped design the study. CC and CLY performed the review. CC and CLY were the main contributors to the manuscript preparation. The three authors were involved in interpreting the data, writing the manuscript and approving the final version. All authors read and approved the final manuscript.

\section{Competing interests}

The authors declare that they have no competing interests.

\section{Consent for publication}

Not applicable.

\section{Ethics approval and consent to participate}

Not applicable.

\section{Author details}

${ }^{1}$ CIAMS, Université Paris-Sud, Université Paris-Saclay, F-91405 Orsay, Cedex France. ${ }^{2}$ CIAMS, Université d'Orléans, F-45067 Orléans, France. ${ }^{3}$ Institut Franco-Européen de Chiropraxie, 72 Chemin de la Flambère, F-31300 Toulouse, France.

Received: 6 October 2016 Accepted: 4 January 2017

Published online: 13 January 2017

\section{References}

1. Andersen LB, Riddoch C, Kriemler S, Hills AP. Physical activity and cardiovascular risk factors in children. Br J Sports Med. 2011;45(11):871-6.

2. Biddle SJ, Gorely T, Stensel DJ. Health-enhancing physical activity and sedentary behaviour in children and adolescents. J Sports Sci. 2004;22(8):679-701.

3. Janssen I, Leblanc AG. Systematic review of the health benefits of physical activity and fitness in school-aged children and youth. Int J Behav Nutr Phys Act. 2010;7:40.

4. Jespersen E, Rexen CT, Franz C, Moller NC, Froberg K, Wedderkopp N. Musculoskeletal extremity injuries in a cohort of schoolchildren aged 6-12: A 2.5-year prospective study. Scand J Med Sci Sports. 2014;25:251-8.

5. Chéron C, Le Scanff C, Leboeuf-Yde C. Association between sports type and overuse injuries of extremities in children and adolescents: a systematic review. Chiropr Man Therap. 2016;24:41. eCollection 2016.

6. Liberati A, Altman DG, Tetzlaff J, Mulrow C, Gotzsche PC, loannidis JP, et al. The PRISMA statement for reporting systematic reviews and meta-analyses of studies that evaluate health care interventions: explanation and elaboration. J Clin Epidemiol. 2009;62(10):e1-34

7. Bahr R. No injuries, but plenty of pain? On the methodology for recording overuse symptoms in sports. Br J Sports Med. 2009:43:966-72.

8. Fuller CW, Ekstrand J, Junge A, Andersen TE, Bahr R, Dvorak J, et al. Consensus statement on injury definitions and data collection procedures in studies of football (soccer) injuries. Br J Sports Med. 2006;40:193-201.

9. Shea BJ, Grimshaw JM, Wells GA, Boers M, Andersson N, Hamel C, et al. Development of AMSTAR: a measurement tool to assess the methodological quality of systematic reviews. BMC Med Res Methodol. 2007;7:10.

10. Kristenson K, Bjorneboe J, Walden M, Andersen TE, Ekstrand J, Hagglund M. The Nordic Football Injury Audit: higher injury rates for professional football clubs with third-generation artificial turf at their home venue. $\mathrm{Br} J$ Sports Med. 2013;47(12):775-81

11. Tegnander A, Olsen OE, Moholdt TT, Engebretsen L, Bahr R. Injuries in Norwegian female elite soccer: a prospective one-season cohort study. Knee Surg Sports Traumatol Arthrosc. 2008;16(2):194-8.

12. Jacobson I, Tegner Y. Injuries among Swedish female elite football players: a prospective population study. Scand J Med Sci Sports. 2007;17(1):84-91.

13. Luthje $P$, Nurmi I, Kataja M, Belt E, Helenius $P$, Kaukonen JP, et al. Epidemiology and traumatology of injuries in elite soccer: a prospective study in Finland. Scand J Med Sci Sports. 1996:6(3):180-5.

14. Nielsen $A B$, Yde J. Epidemiology and traumatology of injuries in soccer. Am J Sports Med. 1989;17(6):803-7.

15. Eirale C, Faroog A, Smiley FA, Tol JL, Chalabi H. Epidemiology of football injuries in Asia: a prospective study in Qatar. J Sci Med Sport. 2013;16(2):113-7.

16. Faude $\mathrm{O}$, Junge A, Kindermann W, Dvorak J. Injuries in female soccer players: a prospective study in the German national league. Am J Sports Med. 2005;33(11):1694-700

17. Ekstrand J, Hagglund M, Fuller CW. Comparison of injuries sustained on artificial turf and grass by male and female elite football players. Scand J Med Sci Sports. 2011;21(6):824-32.

18. Bahr R, Reeser JC. Injuries among world-class professional beach volleyball players. The Federation Internationale de Volleyball beach volleyball injury study. Am J Sports Med. 2003;31(1):119-25.

19. Andersen CA, Clarsen B, Johansen TV, Engebretsen L. High prevalence of overuse injury among iron-distance triathletes. Br J Sports Med. 2013:47(13):857-61.

20. Roos KG, Marshall SW. Definition and usage of the term "overuse injury" in the US high school and collegiate sport epidemiology literature: a systematic review. Sports Med (Auckland, NZ). 2014;44(3):405-21.
Submit your next manuscript to BioMed Central and we will help you at every step:

- We accept pre-submission inquiries

- Our selector tool helps you to find the most relevant journal

- We provide round the clock customer support

- Convenient online submission

- Thorough peer review

- Inclusion in PubMed and all major indexing services

- Maximum visibility for your research

Submit your manuscript at www.biomedcentral.com/submit
Biomed Central 